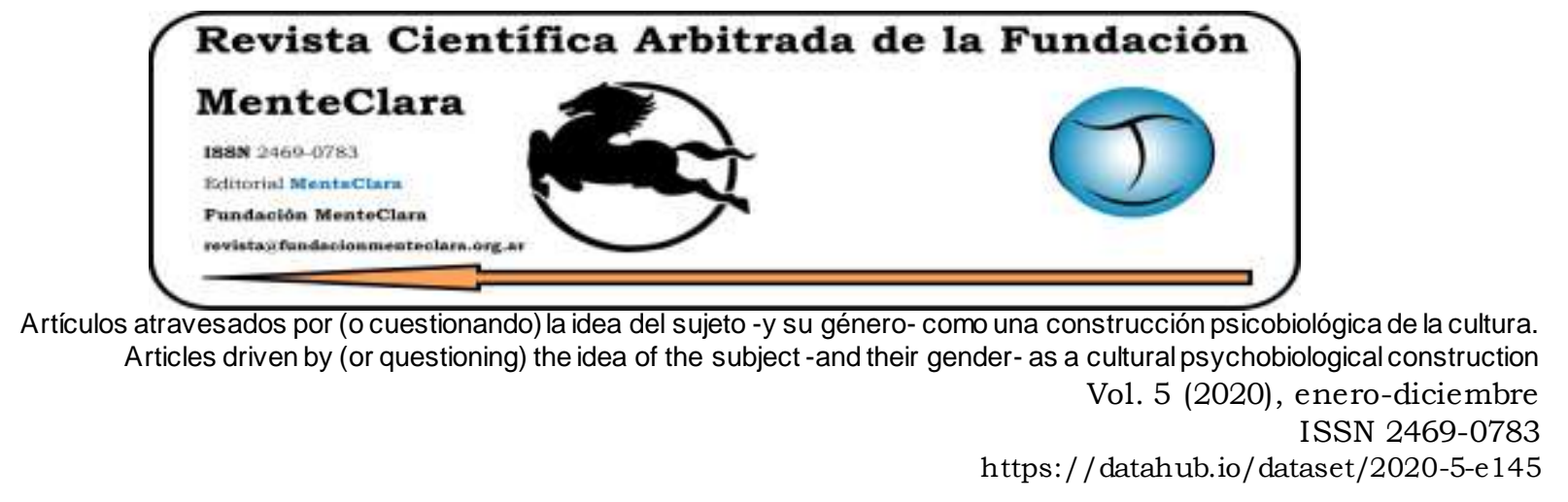

\title{
MAJORITARIAN DEMOCRACY REASSESSED
}

\author{
LA DEMOCRACIA MAJORITARIA REEVALUADA
}

Shuja Shakir shujashakir@rediffmail.com

Dr. Babasaheb Ambedkar Marathwada University, India

Cómo citar este artículo / Citation: Shakir S. (2020). "Majoritarian Democracy Reassessed". Revista Científica Arbitrada de la Fundación MenteClara, Vol. 5 (145). DOI: https://doi.org/10.32351/rca.v5.145

Copyright: (C) 2020 RCAFMC. Este artículo de acceso abierto es distribuido bajo los términos de la licencia Creative Commons Attribution 4.0 International License (CC BY 4.0). Recibido: 13/03/2020. Aceptado: 17/03/2020 Publicación online: 18/03/2020

Conflicto de intereses: None to declare.

\begin{abstract}
This paper attempts to show that while fear of democracy turning into a 'majoritarian' system is rational, it is not always realistic because of the inherent inconsistencies in the idea of 'community cohesion'. Traditional notion of community, constituted by oneness of race, religion, culture or caste, has been seriously contested by upsurge of 'salad bowl' multicultural societies comprising assortment of races, cultures and religions. Even as the trajectories of modern democracies appear to foreground the ethnicisation of its politics, it does not amount to a full-fledged ethnicisation of the communities at large. A thoroughly united community, if there is one, looks real only in the realm of imagination.
\end{abstract}

\section{Resumen}

Este documento intenta mostrar que si bien el miedo a que la democracia se convierta en un sistema "mayoritario" es racional, no siempre es realista debido a las inconsistencias inherentes a la idea de "cohesión comunitaria". La noción tradicional de comunidad, constituida por la unidad de raza, religión, cultura o casta, ha sido 
seriamente cuestionada por el surgimiento de sociedades multiculturales de "ensaladera" que comprenden una variedad de razas, culturas y religiones. Aun cuando las trayectorias de las democracias modernas parecen poner en primer plano la etnicización de su política, no equivale a una etnicización completa de las comunidades en general. Una comunidad completamente unida, si hay una, parece real solo en el ámbito de la imaginación.

Keywords: majoritarian democracy; ethnicity; community cohesion; religious unity Palabras Claves: democracia mayoritaria; etnicidad; Cohe sión comunitaria; unidad religiosa 


\section{Introduction}

Reflections on democracy are laced with a hope that despite being rule by majority democracy will operate within certain philosophical and constitutional constraints that will not to allow it to violate the rights of minorities. Supporters of the democracy wax confident that since a system chosen and built by people themselves cannot become antipeople, any aberration in the stated objective of democracy comes more as an exception than a rule. However, a sense of trepidation prevails, especially about the oft-encountered incapacity of democracy parliamentary democracy in particular - to convert the rule of majority into the rule by consensus that is accommodative of minorities. When a democratic leadership begins to invoke majoritarian sentiment to get elected and harness the liberal institutions to further an anti-minority agenda, it is natural for the apprehensions over the litheness of democracy to arise. The electoral triumph of Donald Trump in US, Erdogan in Turkey and Narendra Modi in India is already broadening those apprehensions (Levitsky \& Ziblatt, 2018).

Democracy sustains in the vote of the majority population, and precisely for that reason, it spawns the threat of majority dominance in a society seething with racial, religious, and caste divides. What is one to do, for instance, if the majority wants an anti-minority legislation passed and votes a favorably inclined government to power to execute it, or the political executive starts exerting an undesirable influence on the democratic institutions to toe a particular ideological line?

It is because of the propensity of the elected representatives to pander to their majority constituency that the questions are raised whether democracy is truly inclusive of minorities in the plural societies. A vociferous champion of representative democracy, John Stuart Mill advocated the need for proportional voting system to ensure the 
protection of minority interests against the majoritarian tendencies in the democracy (Mill, 2010). Gandhi shared similar fears about the possible violation of minority representation in context of the proposed representative democracy in the independent India. Commenting on the representative democracy in Hind Swaraj in 1909, Gandhi wrote, "I pray to God that India may never be in that plight' (Gandhi cited Shankaran, 2019). Gandhi's love for democracy was restricted to his utopian belief in direct democracy where everybody could directly participate in the governance. And in this formulation, he came close to Rousseau who found the possibility of the 'just and indestructible General Will' in some sort of direct democracy (Rousseau, 1993). To Gandhi, representative democracy was not going to work in a multicultural country like India, and he tended to draw from Mill that "democracy was next to impossible in multi-ethnic societies and completely impossible in linguistically divided countries" (Mill cited in Lijphart, 1996).

Multiculturalism is the mainstay of the contemporary societies. Ushered in by the waves of migration in an increasingly globalised world, linguistically and ethnically divided societies are a norm. That has given rise, among other things, to the rejuvenated debates about the political space that minorities should or should not occupy in the lands where they are not supposed to belong. The issue of minority rights has humungous social and cultural implications that the liberal structures of democratic governance are finding difficult to deal with. For example, granting special group rights to the minorities implies welcoming their separate ethnicity, culture and religion into the mainstream culture of the receiving country. What follows is perhaps the biggest dilemma of present-day democracy: what happens to the national unity of the country when you allow different ethnic, racial, religious peoples to live with different sets of rights in one country (Bloemraad et al., 2008)? The 
contradictory political perspectives on how democracy should negotiate the question of ethnic divide have had both the social scientists and the policymakers deeply preoccupied everywhere. However, neither seems to provide a convincing answer.

So, is Gandhi's fear of representative democracy degenerating into anti-people institution coming true? Is the democracy in the country becoming majoritarian in such a way as to facilitate social and political exclusion of the minorities? Have the Indian minorities been reduced to what Lee (2001) calls the 'persistent minorities' who remain minorities, no matter how many times they vote and how many issues they vote on?

\section{Community Cohesion is Unrealistic}

This paper attempts to show while fear of democracy turning into a 'majoritarian' system is rational, it is not always realistic because of the inherent inconsistencies in the idea of 'community cohesion'. Traditional notion of community, constituted by oneness of race, religion, culture or caste, has been seriously contested by upsurge of 'salad bowl' multicultural societies comprising assortment of races, cultures and religions (Kymlicka \& Bashir, 2008). Even as the trajectories of modern democracies appear to foreground the ethnicisation of its politics, it does not amount to a full-fledged ethnicisation of the communities at large. A thoroughly united community, if there is one, looks real only in the realm of imagination.

Even normatively, the concept of majoritarian democracy, singularly dominated by a numerically superior community, looks logically flawed. Going by the way the democratic decision-making happens, one does not usually find individual interests coalescing into a collective interest. Suppose a person wants to buy a car and has an option of choosing from 
two models: an expensive model that comes fitted with a pollution control equipment, and a cheaper model that is without such an equipment. In such a case, buyer is surely not going to pay more to own the expensive model just because it is good for environment. She will, as it were, end up buying the cheaper model even if she favours the pollution control measures in her individual capacity (Hardin, 1990). In other words, a person is focused more deeply on what benefits her individually than the collective benefits resulting from her actions.

\section{Arrow's Impossibility Theorem}

The roots of the argument that individual rankings do not get converted to collective ranking go back to public choice theory associated with Condorcet's 'Problem of Cyclic Majorities' and Kenneth Arrow's 'Impossibility Theorem' (Sen, 1979). Public choice theory establishes in clear terms that democracy cannot just be a tool to incorporate majority opinions. Arrow's Theorem is about the inadequacies of the voting systems and it posits that it is impossible to have fair elections using voter's ranking preferences. Now, the three important conditions of this theorem in respect of democracy are: non-dictatorship, unanimity and independence of irrelevant alternatives. Arrow's theorem says if there a voting system that collects votes based on ranked preferences of the individuals, then it has to violate at least one of the conditions of Theorem (Morreau, 2016). That is, in order to have best among the three existing conditions of theorem, the voting system should discard either one or both conditions. So, because dictatorship is no option in a democracy, the individual voter is likely to discard either unanimity or the independence of irrelevant alternatives, or both. Mostly, it is unanimity that becomes a sacrificial goat for the electoral process to avoid dictatorship. The logical corollary of this is what is also called the 
'favourite betrayal', which means rather than voting for their most favourite candidate, people vote against their least favorite candidate. Of course, Arrow's Theorem, as he himself admitted it, does not establish most voting systems work badly all the times, but the possibility that they can all work badly at times cannot be ruled out.

Arrow's Theorem at least hypothetically proves genuine democracy would be impossible under the present voting system, because no voting system, regardless of its efficiency and utility, can be true represen tative of the voters. Given this imperfectability, one might be tempted to ask whether having such a skewed voting system is good or bad for the democracy. Ironical it might sound; the fact is Arrow's concern may actually make the democracy healthier in the ethnically divided societies by helping it dispense with its majoritarian hue. Since individual interests, in keeping with the postulations of the Theorem, do not aggregate to collective interests, the likelihood of the so-called absolute community coherence founded on the totality of racial, cultural or religious identities remains far from realisation. By way of an example in Indian context, the social and political behaviour of two prominent minorities -Dalit and Muslim- illustrates how the horizontal heterogeneity underlying the communities militates against the prevalent notion of their ethnic or cultural cohesion.

\section{Dalits and Muslims - A Myth of Community Cohesion}

Dalit community or Scheduled castes (SC) have been an integral part of Indian society since time immemorial. History records them as an oppressed group, suffering widespread ostracism and exploitation owing to its degraded social status. After Ambedkarlaunched the emancipatory movement for their entitlement, SCs managed to get the constitutional 
guarantees in form of reservations in jobs and educational institutions in the independent India. Maharashtra state, for example, identifies 59 castes as backward castes and places them in the category of SCs. The basis for bracketing them under one category is the similarity of their socioeconomic background. But then a closer look at their political perceptions and the social behaviour reveals certain contrasting facts. These castes, despite their outward similarities, consider themselves distinct from each other -often so distinct that they would neither interdine nor intermarry. The distance they maintain from each other in several instances is almost akin to the distance the upper castes would traditionally maintain from the lower castes. Studies show that rather than come together as a cohesive group for a greater equality, they tend to begrudge the fact that the better placed categories within SCs eat into what rightfully belongs to them, and thus deprive them of the benefits of the welfare programs of the state. For instance, Matang -a prominent Maharashtrian category of the Scheduled Castes after Mahar- feel disadvantaged because their numerically superior counterparts -mostly Mahar- within the SCs are seen as decamping with a larger share of the pie (Waghmare, 2010).

The case of Muslim community is even more complex. There is a strong perception that Muslims constitute a monolithic social category. They are assumed to live in a close-knit environment with the instrument of fatwa vertically hierarchizing their political decision-making. Such popular perceptions about Muslims also translate to a biased political perspective about them. Muslims are supposed to vote in bloc, vote only for certain parties, and vote strategically to defeat certain parties. The fact is these perceptions are at best misperceptions and at worst symptomatic of ethnic profiling (Verma \& Gupta, 2016). Studies show there are serious internal divisions within the Muslims that neutralise the counterclaim of 
Muslims being monolith. Forinstance, there has been prevalence of caste among Muslims for long, notwithstanding all-round denial of it by the elitist leadership within the community. 1901 Census mentions 133 low castes amongst Muslims with some of them being so low that "no other Muhammadan would associate with them, and who are forbidden to enter the mosque or to use the public burial ground' (Fazl, 2006). Even in politics, "the election data show Muslim support to political parties was never constant" (Shakir, 1990). As for Muslims turning out in huge numbers to vote in masse for particular parties, data from 2004 Lok Sabha elections reveal the turnout among Muslims was lower than the national average in those elections. In fact, in four elections before 2004, the Muslim turnout was $59 \%$ as against the national average of $60 \%$ (Patra, 2006). All this shows Muslim community may not be as cohesive as it is projected in the popular fancies.

But if that is the case, one might ask whether the imperfect voting system leading to a truncated democracy does away altogether with the threats -both real and perceived- to the minorities in an ethnically divided society. It may not. Democracy does harbour prejudices of the majority that often show in its priviledging the numerically superior chunk of the people. Often beneath the pervasive incidence of poverty affecting the Dalit and Muslim population in India, what lurks glaringly is widespread social exclusion grounded in the multiple prejudices (Borooah et al., 2015).

Having said that, it is also important to underline there can never be persistent majority or minority because the communities in reality are never a well-knit mass of people. It is true that political communities are founded on certain identities - common culture, ethnicity, religion or caste - with members drawing their personal identity from the larger community identity and taking pride in flaunting it. Beyond this, 
however, there are grey areas. It is equally true that a community is also a disintegrated conglomerate of divergent constituents, each of which thinks and acts differently from the others. What might appear distinctly cohesive unit from outside might embed gaping fissures inside that may not be easily perceptible, but do exist. People perceived to think along the similar lines due to their social, cultural or economic affiliations may actually not see eye to eye with fellow-members on several critical issues. Similarity of affiliation does not make people similar in their ideas. They can vastly differ in their views from their seemingly similar counterparts within the same cultural, ethnic or religious grouping.

This propensity to divergence - obvious in two minority communities in India-obtains in the majority community as well. The fact is majority community is even more divergent. An analysis of electoral outcomes in India in recent years makes it amply clear. For example, since 2014 most members of majority community have been reported to have voted for Bhartiya Janata Party (BJP) in parliamentary elections, but when it came to elections to state assemblies, they did not vote for the party with as much enthusiasm. That is why despite winning two parliamentary elections with thumping majority since 2014, BJP has put in a poor performance in the states. Now, in terms of Hindu voters preferring BJP, several commentators have argued that majority voters' predilection to BJP was an endorsement of party's explicit Hindutva ideology. That argument begins to look defective because if a voter had indeed voted for an ideology in one election, she should have continued voting for it in the other, given that the penchant for ideology should circumvent the consideration of whether the party has fielded suitable candidates or brought out an appealing manifesto. There is a journalistic hypothesis that if two elections occur with a span of six months, one gets to see an 
identical voting pattern in both. But the Indian voters have proved that hypothesis wrong in last six years.

\section{Conclusion}

It is difficult to see how any community can achieve a perfect similarity of interests. Occupational patterns, linguistic preferences, regional differences, and the motley religious beliefs make the members within one community starkly different from others. To say ethnic identity invariably gets preferentially treated is to overlook the other differentiating indicators that are no less important. In majority cases, when people go to polling booths, they carry multiple issues with them that determine who they will vote for. Mostly, these issues are those of bread and butter, and sometimes also of identity, but identity surfaces only when there is competitive polarisation. Since competitive polarisation is not perennial to any society, there is a hope for the democracy to be simply humanitarian without being either overtly majoritarian or openly minoritarian. 


\section{Referencias}

Bloemraad, I., Korteweg, A., \& Yurdakul, G. (2008). Citizenshipand Immigration: Multiculturalism, Assimilation, and Challenges to the Nation-state. The Annual Review of Sociology, 153-179.

Borooah, V., Sabharwal, N., Diwakar, D., Mishra, V., \& Naik, A. (2015) . Caste, Discrimination, and Exclusion in Modern India. Sage Publications. (s.f.).

Fazl, T. (06 de September de 2006). Dereserve These Myths. The Indian Express.

Hardin, R. (1990). Public Choice Vs. Democracy. Nomos, Vol. 32, Majorities and Minorities, 184-203.

Kymlicka, W., \& Bashir, B. (2008). Introduction: Struggles for Inclusion and Reconciliation in Modern Democracies. En W. Kymlicka, \& B. Bashir, The Politics of Reconciliation in Multicultural Societies (pág. 258). London: Oxford University Press.

Lee, S. (2001). A Paradox of Democracy. Public Affairs Quarterly, Vol. 15. No. 3, 261-269.

Levitsky, S. y Ziblatt, D. (2018). Cómo mueren las democracias . Vikingo. (s.f.).

Lijphart, A. (1996). The Puzzle of Indian Democracy: A Consociational Interpretation. The American Political Science Review, Vol. 90, No. 2 (Jun., 1996), 258-268.

Mill, J. S. (2010). Considerations on Representative Government. Cambridge University Press.

Morreau, M. (2016). Arrow's Theorem. En E. N. (ed.), The Stanford Encyclopedia of Philosophy (Winter 2016 Edition).

Patra, A. (15 de April de 2006). Five Myths about Muslim Vote. The Hindu.

Rousseau, J. J. (1993). Social Contract. Everyman.

Sen, A. (1979). Collective Choice and Social Welfare. Amsterdam: North-Holland.

Shakir, M. (1990). Congress and Minority Vote. En R. Roy, \& S. Sissions, Diversity and Dominance in Indian Politics, Vol.II. New Delhi: Sage.

Shankaran, K. P. (30 de January de 2019). Tyranny of the majority. The Indian Express.

Verma, R., \& Gupta, P. (31 de December de 2016). Facts and Fiction about How Muslims Vote in India - Evidence from Uttar Pradesh. Economic and Political Weekly. Vol. LI. No. 53, págs. 110-116.

Waghmare, B. S. (2010). Re servation Policy and the Plight of Matangs in Maharashtra. The Indian Journal of Political Science, Vol. 71. No. 3 (JULY-SEPT)., 923-946. 